\title{
コモンズに関わる法的課題
}

\section{Legal Issues on Commons}

\section{野口祐子 \\ Yuko NOGUCHI}

クリエイティブ•コモンズ・ジャパン

Creative Commons Japan

森·濱田松本法律事務所

Mori Hamada \& Matsumoto

干100-8222 東京都千代田区丸の内2-6-1

国立情報学研究所

National Institute of Informatics

厂101-8430 東京都千代田区一ツ橋2-1-2

E-mail: yuko.noguchi@mhmjapan.com

\section{1. オープンアクセスの動向}

私はクリエイティブ・コモンズ・ジャ パンという, 著作権関係の NPO の理事を しております。メインは知的財産法関係 の弁護士をしておりまして，普段から特 許権，著作権をどういう風に使うかとい うことについて, 企業の皆さま, 研究者 の皆さま方と情報交換させていただきな がら取り組んでおります。

本日はこのコモンズに関わる法的課題 ということで講演させて頂きます. 現在, BIG DATA の時代ということで, データ が高度化してきていて，しかもその相互 の連携が非常に重要視されてきていると

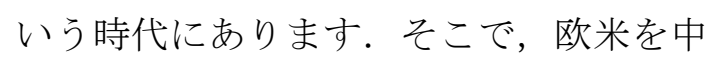
心に，データを共有して，多くの人に見 て貪って，みんなで宝探しをした方がい
いのではないか，というトレンドが，こ こ数年で非常に大きくなってきておりま 于.

世界的には, 2004 年に OECD が, Declaration on Access to research Data from Public Funding を出しております. 企業が 出資している研究開発は，企業がどこか から投資を受ける，もしくは利益を投入 して，そこからさらに利潤を生みだすと いらことが, 前提になっているわけです. しかし，税金，公的資金によってなされ た研究の知的財産は広く国民が貢献した ものですから，それに基づいて利益を生 み出すという, 経済的な必然性が非常に 低いわけで，むしろ国民に還元するのが 筋ではないかという多少哲学めいたとこ 
ろもございます。こうした理由から，特 に公的資金に基づいた研究のデータ共有 について，2004 年頃から提唱がされてい るわけであります。それに基づいて 2007 年に，より具体化したガイドラインが OECD から出ております.さらに 2010 年 の Panton Principles では, データのオープ ンアクセスを確保するために，データや そこへのアクセスを提供するだけでなく， さらに踏夕込んで，もはや権利自体も放 棄したらいいのではないかというところ まで，議論を行っています。

地球観測データでも国連の下で今，推 進事務局があってデータ共有について議 論しておりますし，色々な分野で話が進 んでいるのですが，これらの動きを一番 強力にプッシュしているのは米国である という風に理解をしております。一般に, 知的財産の分野で活動している人は，米 国いうとハリウッド，ハリウッドと言え ば知的財産の強化というのが常識でござ いまして，米国では，デジタル化の技術 が発展とともに, 映画, 音楽等がネット で盗まれている，それを盗まれないよう に如何に保護するかという議論が良く紹 介されています。その一方で，米国は， 科学とは, 音楽, 映画とは別物だという, 非常に巧妙な使い分けを，かなり早期か ら実施しております。そのために，科学 政策はエンターテイメントの囲い込みと は別の考え方でアプローチをしないとい けないという研究，提言を行って，その ための法制度を着々と国内で整えていっ ているわけです。具体的な例として，科 学データでは NIH の Public Data が有名で すし, PubMed Central は研究者の方はど なたでもご覧になっているものかと思い
ます。

日本では，小泉政権下で知的財産の推 進計画，知的財産事務局というものが作 られまして，国力の活性化，知の立国と いう名目の下に，知的財産を強化するこ とで, 国際競争力を上げるということを， 国の知的財産戦略としてやってきたわけ です。そのときに米国がやったような， 分野を分けた差別化や，同じ科学データ でも上流の基礎データはむしろ共有させ て，下流のデータだけ独占させて競争さ せるというような使い分けを日本はあま り導入をしなかったわけです。その結果 としてハリウッド的な考え方が科学にも 広くいきわたって行くような傾向が若干 強く存在しているように思います。公的 資金の研究に対する戦略的，統一的政策 というものが今まで，政府からあまり強 く打ち出されてこなかったというところ が日本の課題であると思います。後ほど 申し上げます通り，今，日本でもここは 変わりつつあるわけですけれども.

米国は, National Research Council が 1997 年から計画的なリサーチをしており まして，それに対応して，次から次と立 法を行っております。データの共有です とか，論文の共有について，国がお金を 付けるのであれば，その引き換えとして， データを必ず共有しなさいという風に， 法律や契約で強制をしているわけです。 それによって統一的なデータベースとい うものを作成しております。棟ではデ ータベースが原則, 各研究者の管理に委 ねられてしまっているために分散化して しまっていて，今統合が非常に大きな課 題になっているのですが，米国は，ある 意味強制的にこれを統合するシステムを 
政府が政策として，実行しているという わけです。

欧州でも，やはり大きなトレンドとし ては，お金を付ける Funding Agency が研 究資金を提供する代わりに，成果として 出てきた論文やデータというのは，こう いう風にオープンにしなさいというポリ シーを採用しているところが増えてきて おります。

このような，基礎データはできるだけ 共有しましょうという大きな流れがある 中で，日本は国際競争力を維持するため にどうすればいいかということを，より 真剣に考えなければいけない時代になっ ているのではないかと考えております。 私個人の意見ですけれども，イノベーシ ヨンを活性化するためには，やはり日本 にもデータ共有センターがあるというこ とは非常に重要ではないかと思っており ます。これをどのように実現するかであ るとか，作ったものをどこまで見せるの かとか, 細かく見ていくと色々な課題が ございます。

しかし，見せると知を盗られるのでは ないかという心配の声をよくききます。 外国にデータを見せたら負けるのではな いかという，もともと負けることが前提 の議論というのは最近良くあります。私 は米国に留学して世界中でたくさんの方 が切硣㻟磨しているのを見ているのです けれども，日本の方が決して優秀ではな いとは全く思わないわけで, 日本の国際 競争力をあげるには、むしろ，環境の整 備, 研究ツールの整備であるとか, お互 いに切硣环磨する環境の整備ということ が，喫緊の課題ではないかという風に思 っています。
なぜ日本におけるデータ共有が必要な のかと言いますと, 日本の, 日本による, 日本のための発明，発見の加速というこ とです。医療データを例にとって見ると 分かりやすいのですが，日本の国民とい うのは，例えば米国の方とは人種的に特 徵が違うかもしれないし, 生活習慣や風 土にも特徵が違うかもしれない. 食生活 ですとか，色々なところが違うわけでし て，米国のデータがあるのだからそれを 見て研究すればいいじやないかと言った としても，それを本当に日本にテーラー メイドなものになるのかというと必ずし もそうはいえないのではないかと思いま す。過激な言葉を使うと，海外の，欧米 の人がやってくれているのだから, 我々 はそれを拝見して，そして自分のデータ は隠し持っていて，うまくやれば一歩先 んじられるのではないかという発想は, だんだん時代遅れになりつつあるのでは ないかと思っております。

実は日本でも動き出しておりまして, 知的財産推進計画 2010 骨子というもの がございまして，この中に公的資金によ る研究成果, 論文および科学データにつ いては，原則としてオープンアクセスを 確保するということが短期目標として挙 げられています。関連省庁として文部科 学省とか, 厚労省, 経済産業省, 農水省 が挙がっておりますので，これからどう いう風に具体化していくかということを 注目していきたいと思います。

\section{2. 知的財産と法的原則}

オープンアクセスを実現するための課 題としては, 技術的課題, 心理的課題, 経済的課題, 組織的課題, そして法律的 
課題が御座いますが，ここでは，法的な 課題について見ていきたいと思います. 法的な課題としては, 著作権, 特許, プ ライバシー, 営業秘密という4つが考え られます。

この 4 つに共通することなのですが， 情報の独占と共有というのはバランスが 問題だということを，忘れがちな場合が ありまして，ここをまず原則として良く 理解しないといけません。近年, 知的財 産の強化のトレンドの中で，とかく自分 が作ったものは原則として全部自分のも のだとお思いの研究者の方が, 非常に増 えてきているような気がするのですけれ ども，実は法律をご覧いただきますと， 自分が発見したものは基本的に独占だと はどこにも書いていないわけです．著作 権でも特許でも，情報というのは実は共 有, 自由が原則になっているということ をまず確認したいと思います。著作権は 事実・アイディアは保護せず, 表現のみ を保護するということで，例えば，この ような遺伝子がこういう働きをするとい う事実そのものは, 著作権では保護され ません，それを論文に書くと，当然，論 文は著作権の保護の対象になるわけです けれど，それは事実をどういう構成で, どういう文言を使って，どのように表現 をしたかということが対象になるわけで して，その中に表現されている事実やア イディアというのは実は著作権では保護 されておりません.

実は，この論文に関する判例というの が既にたくさんございます。よくるの は研究室の中のちょっとした内部紛争で すけれども，共同で開発したのに A さん が勝手に 1 人で論文を書いてしまった,
けしからん，あれは私の著作権が入って いるのですと訴える場合です，結局, 著 作権というのは文章を保護するものです ので，そういう，どなたかが勝手に論文 を書いてしまったというのは，例えば名 誉の侵害であるとか, 研究者倫理として けしからんということで制裁がある場合 があるということはあっても，著作権侵 害ではないということで，著作権という のは事実やアイディアというのはもとも と保護しないということなのです.

これはどうしてかと言いますと，例え ば，報道機関のことを考えていただけれ ばわかるのですが，私が非常に腕の立つ 記者で，あるとき，鳩山首相がこんなこ とをしたという特ダネニュースを取って きて，新聞の 1 面にでかでかと書いたと します，そうすると，たぶん，その日の 夕方にはありとあらゆる夕刊に載ったり を，テレビで報道されたりすると思うの ですけれども，そのように事実そのもの をみんなに紹介できるようにならなけれ ば，結局，知識の共有というものが進ん でいかないのです。ですから，私が最初 に特ダネをつかんで，それを最初に記事 に書いたからと言って，その事実を他の 人が表現するのに，全員が私のところに 来て承諾を取らないといけないというこ とでは世の中が回らないわけです。同じ ように, 特許権についても, 科学法則や 事実の発見そのものは保護されず，産業 分野に応用された発明にのみ独占権が与 えられます。例えば，何か法則を見つけ ましたといっても，それだけでは特許に ならないわけです。少し前に, DNAの塩 基配列そのものが特許になるのではない かということで，米国の研究機関等が特 
許出願をして世の中を騒がせたことがご ざいましたが，結局 DNA の配列という のは事実そのものであって，それだけで 特許ではないということに現在ではなっ ています。それを，例えば何かの診断に 使うとか，それを元に何かの酵素が合成 できたとか薬になったとか，具体的な応 用目的を持って初めて特許として保護さ れます。

つまり，事実や発見というものは，も ともと国民，広く人類と言ってもいいか もしれませんけれども，全体に共有され るべきものだというのが法律の大前提と して存在しているわけです。それによっ て，具体的に論文を書くとか，具体的に 特許発明が生まれるとか, 豊かな研究の 生態系を作っていくということです。よ り下流の応用された，具体的なものにつ いて，どなたかが貢献をすれば，そこの 部分は独占させてインセンティブを与え る，しかしその上の部分というのはむし ろ共有させるというのがもともとあった 法律のバランスなわけです.

データベースを作りますと，そのデー タベースに著作権があるという風に良く 言われるのですけれども, データベース の著作権というのは実は，情報の選択， 体系, 構成に創作性があるものだけでご ざいまして，例えばそのデータベースに 収録されているデータが全部自分の著作 権になるということではないわけであり ます，創作性があるというのは，要する に表現パターンが何通りあるかというこ とだと理解していただければと思います。 要するに, 一定のデータセットを与えら れて，そのデータセット自体は事実であ るので，それをデータベースに組むとき
の組み方が何通りあるかということです. 例えばこれが 20 人やったら 20 通り違う， 100 人やれば 100 通り違うというのであ

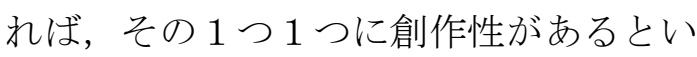
うことになるのかもしれませんが，逆に 良く言われるのが，例えば名簿を，アイ ウエオ順に並べるというのは誰でも思い つくことですし，アイウエオ順に並べれ ば誰でも結果は同じようになるわけです から，そういうありふれたパターンをし たものは創作性がないという風に言われ ております。

したがって，データベースも著作権が あるものとないものがございまして，む しろ科学データベースなどは, ないもの が実はそれなりにあるのではないかとい うことが議論されています。そうなりま すと，著作権があるのかないのかよくわ かりませんし，仮になかったとしても， これは私が作ったものなのだから利用す るにはそれなりに条件を付けたいと思う のが，研究者の方としては自然な発想で して，著作権があってもなくても，公開 にあたって利用条件を示すポリシーを作 るということがよく行われるわけです。 これにはメリットもございます，利用条 件を書く，というのは権利者から見て， 自分が想像しない使われ方を防止するこ とができます。利用者から見たときも， 何が出来て何が出来ないのかということ がよくわからないと，どこまでどんな風 に使っていいのかよくわからない，結局 その研究者の方に確認をとったりするコ ストが色々あるわけで，利用条件にはそ ういう意味でコストを節減できたりとか, 委縮効果を防いだりというようなメリッ トがあります。問題はその利用条件をど 
のような内容でつけたらいいかというこ とです.

\section{3. 標準化されたライセンス}

その利用条件ですが，標準化されたも のと，カスタマイズされたものがござい ますが，標準化されたものを使用するこ とをお勧めしたいと思います。現在，デ ータを出そうと決意してホームページに 載せられている方というのは，多かれ少 なかれ皆さんに使ってほしいと思ってい らっしゃると思うのですけれども，そう いう時に，この標準化されたライセンス を使いましょうということです。標準化 されたライセンスを用いるメリットは, 技術の標準化と同じで，ライセンスとい うインフラが統一されると，相互互換性 が高まったり，ライセンスは 1 回勉強す ればあとは全部同じなわけですから，毎 回，毎回一所懸命それぞれのライセンス を読んで，毎回，毎回頭を悩ませるコス トが下がるということがございます。

けれども，このお話をしますと研究者 の方から，「しかし私が欲しい条件は入 っていないんです」とか，「この条件が 気に入らないんです」というような話を 良く頂きます.どうしても $100 \%$ 自分が望 むものにしたいという風に考えますと， 自分が希望の条件を全部盛り込んだカス タマイズしたライセンスにしたいという 気持ちが発生するのはある意味当然です。

しかし，全部自分の希望条件を入れて 公開すると，公開する側としては非常に 安心感があるわけですが，これだと 1 次 公開はそれで進む可能性があるのですが, その後がつまずいてしまうということが しばしばあります，Aさんの条件と Bさ
んの条件とそしてCさんの条件が全然違 っていると，それを 1 つ 1 つ読むのも大 変ですし，A さんはこれはしてはいいけ どこれは駄目と言っていて，Bさんがこ れは駄目だけどこれはいいと言っていて， そうすると，この 2 つは結局両立しない から，Aさんと Bさんのデータを同時に 使う研究は駄目なのかなあとか，非常に 複雑な問題がそこに出てきてしまうわけ です。

したがって，多少気に入らないところ があっても，大きな目で見て基本的に良 ければ，やっぱり標準化したものを使う という割り切りが非常に重要でございま す。弁護士という目で言わせていただく と，公開する前には非常にいろんなこと を考えます。特に理系の方は非常に緻密 でいらっしゃるので，ありとあらゆるパ ターンを想定して非常に細かいことまで, あんなこともある，こんなこともあるか もと，条件を沢山入れたがるのですけれ ども，実際にそういうトラブルが起こる とことはめったにないので，あまりそこ に労力を割くと，公開する側も利用する 側も結局不要なコストを強いられるとい うことで，もう少し大まかに考えていた だければいいのではないかなという風に 考えています。

ライセンスの互換性に関しては、 Wikipedia が 2009 年にライセンスを切り 替えました. GFDL というライセンスを 使っていたのですけれども，それをクリ エイティブ・コモンズ(CC)のライセンス も使えるようになりました。両方とも非 常に似たライセンスなのですが，一度ラ イセンスを決めてしまうと，なぜかそこ に愛着が発生したり，色々なしがらみが 
発生しまして, CC ライセンスを採用する のに, 3 年も 4 年も協議をするという大 変な経験を致しました。そういう意味で 最初のライセンスを選ぶときによく考え て選ことが重要だということを是非お考 えいただきたいと思います。

\section{4. サイエンス・コモンズ}

科学の分野ではサイエンス・コモン ズ・プロジェクトというのがございまし て, これは, NPO クリエイティブ・コモ ンズの中で，科学情報に特化したプロジ ェクトです，主に行っていることは，共 有をどのように進めたらよいかというよ うなことを考えて，提案をして，その手 順を示すプロトコルを作ったり，こうい うライセンスがお勧めですよという標準 ライセンスを作って，ルールの標準化に 取り組むといったことです，日本ではサ イエンス・コモンズ翻訳プロジェクトと いうのがございまして，まず web ページ の翻訳から始めております。

サイエンス・コモンズがどんな提案を しているか，論文とデータに関するもの だけ簡単にご紹介したいと思います。

論文については, CC の表示ライセンス というライセンスの使用を提案していま す。表示ライセンスというのは，権利者 の名前を表示すれば，複製や改変，公衆 送信等はすべて自由にやっていいですよ というライセンスです。当初の論文の才 ープンアクセスというのは, 研究者がと りあえずダウンロードして読めればいい のではないか，したがってプリントアウ トさえできればいいのではないかという 話がありました。しかし, 最近はオント ロジーを作ったり，色々なセマンティッ
クな処理をするのに，複製だけではやっ ぱり駄目で，その中の文章を色々抜き出 してきて，場合によって，入れ替えてみ たり，それをまた皆さんに発信したりと いうことが出来ないと, 科学論文の価值 を最大限に引き出すということはもはや できない時代になってきております。従 って，読めればいいということではなく て, 改変や公衆送信も含めて可能として くださいという提案をしております.

これに対しまして，データはもっとあ る意味先端というか，権利放棄をすると いうことを提案しております。このお話 をすると，ほとんどの研究者の方は最初 驚かれることが多いのですが，この提案 はそれなりの理由がございます。かつて は，サイエンス・コモンズもデータの著 作権について権利放棄を提案していたわ けではないのです. 2007 年だったか 2008 年だったかと思いますけど，弁護士を集 めてタスクフォースを中で作りまして， データを公開するのに利用条件があまり にもばらばらで，これは問題である，し たがって統一的な利用条件のライセンス を我々で研究して，そして現在公開され ているデータの条件は誰に対してどうな っているか，まずみんなで読んでみまし ようということを行いましたそそのうえ で，どれが一番すぐれているかというこ とを，我々の中で考えて，そして研究者 の関連の方々にいろいろヒアリングをし て，そしてスタンダードな，推奨のライ センスを作りましょうというプロジェク 卜を，世界中から弁護士を 10 人くらい集 めて，始めたわけです。

ところが，この弁護士が毎日取つ組み 合いのけんかになりまして。これをどう 
読むのか, どう解釈するのか, これとこ れは同じ意味なのか, 違うのか.これと これは組み合わせが出来るのか，出来な いのかという, 非常に複雑なパズルを 10 人くらいで毎日議論した結果, 途中で疲 労困供致しまして，これを弁護士がやっ てもできないのに，法律のトレーニング を受けていない科学の研究者の方が弁護 士に相談しないで自分で理解できるかと いうと，絶対ノーだという，確信に至り ました。したがって，データの条件とい うのはできるだけ自由にして，利用の公 正さは，そのコミュニティの倫理のルー ルであったり，モラルであったりとか, 元からある色々なルールで担保できるの だから，こういう不毛な消耗戦はやめよ うという結論に至りました。その結果と して，この権利放棄というものを提唱す るに至っているわけです。ただ，世界中 では全員がこれに納得しているというわ けではなく, 色々な見解も出ているとこ ろでございます.

著作権問題が解決しても, さらに特許 権の問題があるということは研究者の方 はもう既にご存知かと思いますけれども， 特許権のクリアランスにつきましてはい くつか方法が提唱されております.

一つはパテント・プールの問題です. その分野で特許を持っている人たちがみ んな持ち寄ってお互いにこれを作りまし ようということです。これはこれで色々 な課題がございまして，隠し持っていて なかなか出てこない人をどう説得するか とか, あまり有力者が集まり過ぎると独 禁法の問題があるといったことがござい ます.この動きは 2010 年の知財計画でも 紹介されておりますけども, 特に標準化
技術についてのどのようにするかという ことで議論をこれから活発していこうと 日本の政府も提唱しております。同じ事 がこのコモンズの場面でも発生しうると いうことです．先ほどの著作権ライセン スと同じように，特許もあらかじめライ センスを付ければいいじゃないかという ことで，パテントコモンズというプロジ エクトをサイエンス・コモンズが始めて おりまして，今標準のライセンスのドラ フティングに取り掛かっているところで す。エコパテントコモンズという，環境 技術に配慮したものを企業から集めて, ライセンシングするというプロジェクト が，実際に動き出しています。

あとは，プライバシーの問題がござい ます，これは，非常に難しいのであまり 立ち入らないようにしたいとは思うので すけれども，特に人にまつわるデータに ついてはプライバシーの問題は非常にセ ンシティブでございますので, そこは慎 重にやらないといけないというのがある のです，個人情報保護法上は個人名が特 定できなければいいということで，良く あるのは完全に名前との結びつきを取っ てしまって, 統計の形にしてしまったり, 年齢や性別とかで名前が特定できないよ うにすれば，非常に特殊な病気であった り，遺伝子データそのものに関するもの 以外はいいのではないかというような議 論がされています。これを必要以上に厳 しく解釈していらっしゃる方もいらっし やって, 名前の完全に切り離されたデー タであっても, 一番最初に取得したイン フォームド・コンセントの範囲外だと使 えないんじゃないかという議論がまだ一 部ではされているようですので, 今後さ 
らに議論を進めていくことが必要だと思 います。

最後に, 営業秘密の問題ですけれども, 営業秘密というのは知られていなくて, かつ秘密として管理されている情報のこ とを営業秘密と呼んでいます，研究者の 方からは, データは私の営業秘密です, 営業秘密は公開できないことになってい るので，したがって公開はできません， というお返事がしばしば返ってくるので 寸けれども，営業秘密にするかしないか は誰かが決めたわけではなく, 自分が戦 略的に決める問題なのです.したがって, 営業秘密だから開示できないのではなく て，開示しないと決めたものが営業秘密 なのだということです．非常に似ている ようですが，大きな違いがあります。逆 にオープンにすることと営業秘密とのメ リット，デメリットが良く言われます. 公開する一番大きなメリットは，公開す ることによって隠していた情報について，
第三者から特許を取られてしまって，あ る日突然第三者から「これは私の特許で す」と言われて使えなくなってしまうと いうことが防げるということです。特許 出願でよく防衛的特許出願という話がさ れますが，特許を出さなくても，その情 報を公開しただけで特許性はもう失われ るわけです. 従って, 自分の研究分野で, 基礎分野，基礎事実については，むしろ オープンにして防衛的に保護していくと いう考え方もあるということであります。

以上，色々お話させていただきました が, 本日, 私が一番言いたいことは, 戦 略的にオープン化をもう少し考えていき ましょうということと，公開する際のラ イセンスは, カスタマイズしょうという ことではなく，標準化されたライセンス の使用を考えよう，ということの 2 点で 于.

ご清聴どうもありがとうございました。 